\title{
Core Principles and Global Practices of Deposit Insurance Scheme: A Comparison of the Trend with the Nepalese System
}

\author{
Kiran Prasad Bhatta, PhD \\ Research and Program Director, Nepal Bankers' Association \\ Email: nba@enet.com.np
}

\begin{abstract}
Banks are in the business of assuming and managing risks and by virtue of this they are vulnerable to liquidity and solvency problems. Since, banks rely on customer deposit that can be withdrawn on little or no notice, they are prone to bank-runs, where depositors seek to withdraw funds quickly ahead of the possible bank insolvency. Policy makers thus maintain deposit insurance scheme to protect depositors and to give them comfort that their funds are not at risk.
\end{abstract}

Deposit insurance or deposit guarantee, as known in Nepal, has been recently introduced by the government of Nepal. While introducing it a thorough study does not seem to have been conducted and government or the central bank seem to have introduced it all of a sudden. There are a lot of contentious issues that even the government agencies seem not be clear of. This research, thus, seeks to find out the basic principles of effective deposit insurance system, the practices and trend in the different countries throughout the world, with emphasis on the South Asian countries, and compare it with the Nepalese context. The research also explores and highlights the major contentious issues in the Nepalese case. The primary data of this research is drawn from existing literature on deposit insurance as well as website of central banks and governments of different countries. Thus, it is a Review Research.

It was found that there are several issues in the Nepalese deposit insurance scheme that need to be addressed based on best international practices and based on basic principles of deposit insurance system. As per the core principles of an effective deposit insurance scheme, policy makers should prepare a way out for the Nepalese deposit insurance system. Based on the findings of this research, it is recommended that at least following improvements need to be done: Deposit and Credit Guarantee Corporation of Nepal be provided explicit backing from the Central Bank and/or Government of Nepal so that depositors have full confidence on the scheme; public awareness campaign be initiated for enhancing the effectiveness of the system; deposit should be refunded to the depositors on demand anytime even if the bank is being under consideration to be declared problematic or is being referred for liquidation in order to make them feel the existence of the deposit insurance scheme; depositors not be made a scapegoat and cent-percent guarantee of deposits be made; function of both deposit and credit guarantee not be provided to a same institution rather two separate entities be made; and deposit insurance premiums be revised. Besides, it would be better to improve the supervisory capacity of the central bank since with the introduction of deposit insurance scheme banks are prone to increased risk; possibility of co-insurance 
should be looked after; and possibility of establishing Asset Management Company and introducing Rating Agency should be explored.

Since, one of the major issue of controversy seems to be the premium rate, which is very high compared to other neighboring countries as well as compared to developing and under-developed countries, it need to be revisited. In this context, this research proposes that the policy makers and/or regulators should try to make differential premium rates as follows: Class A: $0.05 \%$; Class B: $0.10 \%$; Class C: $0.20 \%$; Class D: $0.10 \%$. Or if it is not deemed to be appropriate at present, a flat rate of $0.10 \%$ will be appropriate for the time being.

\section{INTRODUCTION}

Banks and financial institutions (hereinafter referred to as banks) are allowed and/or encouraged to lend or invest most of the money deposited with them instead of safe-keeping the full amounts. By their nature, banks are vulnerable to liquidity and solvency problems, among other things, because they transform shortterm liquid deposits into longer-term, less-liquid loans and investments. They also lend to a wide variety of borrowers whose risk characteristics are not always readily apparent (FSF, 2001). Thus, banks are in the business of assuming and managing risks.

If many of a bank's borrower fail to repay their loans when due, the banks' debtors including its depositors risk loss. Since, banks rely on customer deposit that can be withdrawn on little or no notice, banks are prone to bank run, where depositors seek to withdraw funds quickly ahead of possible bank insolvency. Bank runs occur if individuals decide to withdraw their deposits en-masse in an attempt to avoid individually suffering losses should the bank need to liquidate its loans. Runs cause disruptions to bank-dependent borrowers. If individuals shift out of bank deposits and hoard currency, runs also have a monetary impact that is deflationary (Pennacchi, 2009).

Banks that accept deposits from the public are important in the economy because of their involvement in the payments system, their role as intermediaries between depositors and borrowers, and their function as agents for the transmission of monetary policy (FSF, 2001). The importance of banks in the economy, the potential for depositors to suffer losses when banks fail, and the need to mitigate contagion risks, lead several countries throughout the world to establish financial safety nets. A financial safety net usually includes prudential regulation and supervision, a lender of last resort, and deposit insurance. Policy makers thus maintain deposit insurance scheme to protect depositors and to give them comfort that their funds are not at risk. While these measures did not address the root causes of the lack of confidence, they were nevertheless helpful in avoiding a further accelerated loss of confidence, thus buying valuable time (Schich, 2008). A bank's ability to create liquid transactions deposits can break down if its capital declines and default risk rises. In this circumstance, deposit insurance restores deposit liquidity by making deposits default-free (Pennacchi, 2009). 
Deposit insurance protects insured depositors against the consequences associated with the failure of a bank, but is not designed to protect banks from failing. The provision of deposit insurance relieves insured depositors of the difficult tasks of monitoring and assessing the condition of banks and their asset quality. Deposit insurance system can deal with a limited number of simultaneous bank failures, but cannot be expected to deal with a systemic banking crisis by itself.

The principal objectives of deposit insurance system are to contribute to the stability of the financial system and to protect less-financially-sophisticated depositors. Thus, deposit insurance creates a safe savings vehicle for small, unsophisticated individuals. If such individuals lack access to low-risk investments other than bank deposits, then deposit insurance transforms their default-risky bank debit into an investment that is default-free (Pennacchi, 2009). A trustworthy system that protects deposits should allow depositors to transact freely with financial institutions, reducing the social costs involved (Choi, 1999). A welldesigned and well-understood deposit insurance system contributes to the stability of a country's financial system by reducing the incentives for depositors to withdraw their insured deposits from banks because of a loss of confidence. Besides, another rationale for deposit insurance relates to financial and monetary stability (Pennacchi, 2009).

The introduction of a deposit insurance system can be more successful when a country's banking system is healthy. To be credible, a deposit insurance system needs to be properly designed ${ }^{1}$, well implemented, and understood by the public ${ }^{2}$. It also needs to be supported by strong prudential regulation and supervision, sound accounting and disclosure regimes, and the enforcement of effective laws.

The first step in designing a deposit insurance system is to identify the public-policy objectives that it is expected to achieve and these objectives must be well understood. Although the determination of such objectives is the responsibility of governments, the private sector can play a role in their achievement (FSF, 2001). In conjunction with the identification of public-policy objectives, policymakers should conduct a situational analysis to guide their decision-making.

Among the conditions and factors that should be taken into consideration are: the level of economic activity; current monetary and fiscal policies; the state and structure of the banking system; public attitudes and expectations; the legal framework; prudential regulatory, supervisory, accounting and disclosure regimes. However, the ultimate choice of how a deposit insurance system is to be operated depends on many factors that are unique to each country and its governmental and financial systems (FSF, 2001).

Deposit insurers are mostly government run or government established institutions, and may or may not be a part of a country's central bank, while some are private entities with government backing or completely private entities in a very few cases, if any. There is no single mandate or set of mandates suitable for all deposit insurers. Existing deposit insurers have mandates ranging from narrow, so-called 
"pay-box" system ${ }^{3}$ to those with broader powers and responsibilities, such as "riskminimization" system ${ }^{4}$, with a variety of combinations in between.

Regardless of the scope of a deposit insurer's mandate, there are certain structural and operational issues that must be addressed. One of the first tasks is to determine whether the deposit insurance function should be assigned to an existing organization or whether a separate entity should be established. Similarly, there are a variety of forms of governance that can be used by a deposit insurance system. The form of governance utilized should reflect the mandate and the degree to which the deposit insurer is legally separated from other financial safety-net participants.

Besides, the ability to attract and retain qualified employees is a key challenge for most deposit insurers throughout the world. This is important since the insurers need human resources who have an understanding of banking issues, legal issues, as well as the role of regulators. The importance of statutory indemnification should be recognized and employees should receive legal protection against lawsuits for their actions taken in good faith. Again, the policymakers should address the deposit insurer's relationships and coordination with the other safety-net participants. A need for close coordination exists in any institutional setting and information sharing among safety-net participants is essential.

When a deposit insurance system is created, policymakers are faced with the challenge of minimizing the risks to the deposit insurer, while granting extensive membership. Generally, two options are available: automatic membership or requiring banks to apply for entry. Automatic membership for all banks may be the simplest option in the short term. However, the deposit insurer may then be faced with the difficult task of having to accept banks that create an immediate financial risk or that pose other adverse consequences for the deposit insurance system. Alternatively, banks may be required to apply for membership. This option provides the deposit insurer with the flexibility to control the risks it assumes by establishing entry criteria. It also can serve to enhance compliance with prudential requirements and standards. In such cases, an appropriate transition plan should be in place that details the criteria, process and time frame for attaining membership. The criteria should be transparent.

Although domestically incorporated banks are the principal members of most deposit insurance system, some countries require foreign-bank subsidiaries and branches to participate in the system as well. Similarly, policymakers take different approaches to non-bank financial institutions that offer deposits and deposit-like products. State-owned banks present unique issues for deposit insurance system. These banks are usually the beneficiaries of an implicit or full government guarantee that may make their inclusion in a deposit insurance system appear unnecessary. Nevertheless, some countries have chosen to include them in their systems.

Policymakers should define clearly in law or by private contract what is an insurable deposit. Once the relevant deposits are selected, exclusions of specific deposits 
and/or depositors can be determined. Again, once the scope is determined, the level of coverage can be set. However, policymakers should consider the relationship between coverage levels and moral hazard. One approach to foster market discipline and to reduce the costs of deposit insurance is the use of coinsurance, whereby a pre-specified proportion of deposits are only insured.

Explicit deposit insurance is a measure implemented in many countries to protect bank depositors, in full or in part, from losses caused by a bank's inability to pay its debts when due. In an implicit deposit protection scheme, losses arising from the insolvency of a financial institution are borne by the general public, regardless of income, size of individual deposit, or size of the financial institution. Such a deposit protection scheme cannot be seen as fair (Choi, 1999).

Sound funding arrangements are critical to the effectiveness of a deposit insurance system and the maintenance of public confidence in this scheme. A deposit insurance system should have available all funding mechanisms necessary to ensure the prompt reimbursement of depositors' claims after a bank failure. Inadequate funding can lead to delays in resolving failed banks, to significant increases in costs, and a loss of credibility of the deposit insurance system. Funding can be assured in many ways, such as government appropriations, levies or premiums assessed against member banks, market borrowings, or a combination thereof. Usually, member banks need to pay the cost of deposit insurance, since they and their clients directly benefit from having an effective deposit insurance system. Policymakers should consider the effect of premium levels on the financial health of the banking industry, and an assessment base should be chosen against which a given premium rate will be applied.

Deposit insurance system has been already established in several countries. The United States is most probably the first country to insure the deposits, by establishing the Federal Deposit Insurance Corporation in 1933. However, Nepal has recently moved forward in this process. From the $\mathrm{FY}^{5}$ 2009/10, GON envisaged implementing deposit guarantee scheme and NRB also announce it though its Monetary Policy (NRB, 2009) and later on prepared a draft Concept Paper on the same. From the same year, deposit guarantee scheme has been initiated with the D-Class banks and then gradually increased its coverage to A-Class banks from the FY 2011/12. However, neither the regulators nor the government had conducted any rigorous studies regarding various aspects of deposit guarantee (deposit "guarantee" and "insurance" has been interchangeably used throughout this paper). There is a lack of research in this aspect. Hence, this research envisages to fulfill this gap, although partially. The specific objective of this study is to:

- Discuss the underlying principles for effective deposit insurance system;

- Analyze different deposit insurance scheme around the world;

- Compare deposit insurance schemes of several countries with that of Nepal;

- Determine whether Nepalese deposit insurance is in line with best international practices; and

- Provide appropriate suggestions for increasing the efficacy of Nepalese deposit insurance scheme. 


\section{METHODOLOGY}

This research is based on the review of existing literatures on the deposit insurance system (deposit insurance "system" and "scheme" is interchangeably used throughout this paper). Principles of effective deposit insurance system as well as the deposit insurance system over the world (selected countries) are looked after. Thus it is a Review Research. Internet search is conducted to find out major deposit insurance schemes of the selected countries, with primary focus on South Asian countries. Websites of Central Banks of the selected countries, thus, served as the primary data for this research. National laws related to deposit insurance system is also searched from the websites of different nations. Some literature on deposit insurance is also collected to observe the developments in the theory and academics.

Comparisons are then done to analyze the similarities and difference between provisions of different countries regarding the deposit insurance system. Comparative analysis of selected countries is done against that of Nepal. Tabulation of major variables is done to analyze the basic characteristics of major deposit insurance system of the world. Nepalese deposit insurance system is then discussed in detail. Based on these discussion, the present scenario of Nepalese deposit insurance scheme is presented along with the recommendation for improving the major shortcomings.

\section{DISCUSSION}

\subsection{Core Principles and preconditions to Effective deposit guarantee} Systems

Policymakers have choices regarding how they can protect depositors and contribute to the financial system stability. Explicit deposit insurance has become the preferred choice compared to other alternatives such as reliance on implicit protection. The introduction or the reform of a deposit insurance system can be more successful when a country's banking system is healthy and its institutional environment is sound. A deposit insurance system is not intended to deal, by itself, with systemically significant bank failures or a "systemic crisis". In such cases all financial system safety-net participants must work together effectively. The Core Principles are reflective of, and designed to be adaptable to, a broad range of country circumstances, settings and structures. The Core Principles are intended as a voluntary framework for effective deposit insurance practices (BIS, 2009).

An effective deposit insurance system needs to be based on a number of external elements or preconditions. These preconditions include: an ongoing assessment of the economy and banking system; sound governance of agencies comprising the financial system safety net; strong prudential regulation and supervision; and a well developed legal framework and accounting and disclosure regime.

The 18 Core Principles are broadly categorized into ten groups as follows:

1. Setting objectives (Public policy objectives; Mitigating moral hazard)

2. Mandates and powers (Mandate; Powers)

3. Governance (Governance) 
4. Relationships with other safety-net participants and cross-border issues (Relationships with other safety-net participants; Cross-border issues)

5. Membership and coverage (Compulsory membership; Coverage; Transitioning from a blanket guarantee to a limited coverage deposit insurance system)

6. Funding (Funding)

7. Public awareness (Public awareness)

8. Selected legal issues (Legal protection; Dealing with parties at fault in a bank failure)

9. Failure resolution (Early detection and timely intervention and resolution; Effective resolution processes)

10. Reimbursing depositors and recoveries (Reimbursing depositors; Recoveries)

The Principles are discussed below (based on BIS, 2009):

Principle 1: Public policy objectives

The first step in adopting a deposit insurance system or reforming an existing system is to specify appropriate public policy objectives that it is expected to achieve. These objectives should be formally specified and well integrated into the design of the deposit insurance system. The principal objectives for deposit insurance systems are to contribute to the stability of the financial system and protect depositors.

Principle 2: Mitigating moral hazard

Moral hazard should be mitigated by ensuring that the deposit insurance system contains appropriate design features and through other elements of the financial system safety net.

Principle 3: Mandate

It is critical that the mandate selected for a deposit insurer be clear and formally specified and that there be consistency between the stated public policy objectives and the powers and responsibilities given to the deposit insurer.

Principle 4: Powers

A deposit insurer should have all powers necessary to fulfill its mandate and these powers should be formally specified. All deposit insurers require the power to finance reimbursements, enter into contracts, set internal Core Principles for operating budgets and procedures, and access timely and accurate information to ensure that they can meet their obligations to depositors promptly.

Principle 5: Governance

The deposit insurer should be operationally independent, transparent, accountable, and insulated from undue political and industry influence.

Principle 6: Relationships with other safety-net participants

A framework should be in place for the close coordination and information sharing, on a routine basis as well as in relation to particular banks, among the deposit insurer and other financial system safety-net participants. Such information should be accurate and timely (subject to confidentiality when required). Informationsharing and coordination arrangements should be formalized. 
Principle 7: Cross-border issues

Provided confidentiality is ensured, all relevant information should be exchanged between deposit insurers in different jurisdictions and possibly between deposit insurers and other foreign safety-net participants when appropriate. In circumstances where more than one deposit insurer will be responsible for coverage, it is important to determine which deposit insurer or insurers will be responsible for the reimbursement process. The deposit insurance already provided by the home country system should be recognized in the determination of levies and premiums.

Principle 8: Compulsory membership

Membership in the deposit insurance system should be compulsory for all financial institutions accepting deposits from those deemed most in need of protection (e.g. retail and small business depositors) to avoid adverse selection.

Principle 9: Coverage

Policymakers should define clearly in law, prudential regulations, or bylaws what an insurable deposit is. The level of coverage should be limited but credible and be capable of being quickly determined. It should cover adequately the large majority of depositors to meet the public policy objectives of the system and be internally consistent with other deposit insurance system design features.

Principle 10: Transitioning from a blanket guarantee to a limited coverage deposit insurance system

When a country decides about transition from a blanket guarantee to a limited coverage deposit insurance system, or to change a given blanket guarantee, the transition should be as rapid as country's circumstances permit. Blanket guarantees can have a number of adverse effects if retained too long, notably moral hazard. Policymakers should pay particular attention to public attitudes and expectations during the transition period.

Principle 11: Funding

A deposit insurance system should have available all funding mechanisms necessary to ensure the prompt reimbursement of depositors' claims including a means of obtaining supplementary back-up funding for liquidity purposes when required. Primary responsibility for paying the cost of deposit insurance should be borne by banks since they and their clients directly benefit from having an effective deposit insurance system. For deposit insurance systems (whether ex-ante, ex-post or hybrid) utilizing risk adjusted differential premium systems, the criteria used in the risk-adjusted differential premium system should be transparent to all participants. As well, all necessary resources should be in place to administer the risk-adjusted differential premium system appropriately.

Principle 12: Public awareness

In order for a deposit insurance system to be effective it is essential that the public be informed on an ongoing basis about the benefits and limitations of the deposit insurance system. 
Principle 13: Legal protection

The deposit insurer and individuals working for the deposit insurer should be protected against lawsuits for their decisions and actions taken in "good faith" while discharging their mandates. However, individuals must be required to follow appropriate conflict-of-interest rules and codes of conduct to ensure they remain accountable. Legal protection should be defined in legislation and administrative procedures, and under appropriate circumstances, cover legal costs for those indemnified.

Principle 14: Dealing with parties at fault in a bank failure

A deposit insurer, or other relevant authority, should be provided with the power to seek legal redress against those parties at fault in a bank failure.

Principle 15: Early detection and timely intervention and resolution

The deposit insurer should be part of a framework within the financial system safety net that provides for the early detection and timely intervention and resolution of troubled banks. The determination and recognition of when a bank is or is expected to be in serious financial difficulty should be made early and on the basis of well defined criteria by safety-net participants with the operational independence and power to act.

Principle 16: Effective resolution processes

Effective failure-resolution processes should: facilitate the ability of the deposit insurer to meet its obligations including reimbursement of depositors promptly and accurately and on an equitable basis; minimize resolution costs and disruption of markets; maximize recoveries on assets; and, reinforce discipline through legal actions in cases of negligence or other wrongdoings. In addition, the deposit insurer or other relevant financial system safety-net participant should have the authority to establish a flexible mechanism to help preserve critical banking functions by facilitating the acquisition by an appropriate body of the assets and the assumption of the liabilities of a failed bank (e.g. providing depositors with continuous access to their funds and maintaining clearing and settlement activities).

\section{Principle 17: Reimbursing depositors}

The deposit insurance system should give depositors prompt access to their insured funds. Therefore, the deposit insurer should be notified or informed sufficiently in advance of the conditions under which a reimbursement may be required and be provided with access to depositor information in advance. Depositors should have a legal right to reimbursement up to the coverage limit and should know when and under what conditions the deposit insurer will start the payment process.

\section{Principle 18: Recoveries}

The deposit insurer should share in the proceeds of recoveries from the estate of the failed bank. The management of the assets of the failed bank and the recovery process (by the deposit insurer or other party carrying out this role) should be guided by commercial considerations and their economic merits. 


\subsection{Major issues with Nepalese deposit insurance system}

As Demirguc-Kunt et al. (2008) has rightly said deposit insurance is more likely to be adopted during financial crises, presumably because representatives for sectoral interests find it easier to negotiate regulatory reform in distressed circumstances. NRB also initiated the process of insuring deposit with the observance of first case of failure of a licensed institution, namely Nepal Development Bank Ltd. (NDB). Although, informal news reports suggest that deposits up to NPR 800,000 of NDB has been returned to the depositors and almost $80 \%$ of the liabilities (or even more) has been paid up, but the case put the hand of regulators above and they push through the enactment of deposit insurance regulations. Now, all the licensed institutions of NRB mandatorily need to participate in the deposit insurance scheme provided by Deposit and Credit Guarantee Corporation of Nepal (DCGC) ${ }^{7}$.

Deposit insurance protects insured depositors against the consequences associated with the failure of a bank but it is not designed to protect banks from failing (FSF, 2001). Instead, as accepted by NRB itself in its draft Concept Paper on deposit insurance, it may increase the cases of moral hazard, if specific rules and regulations could not be implemented effectively. Thus, however deposit insurance scheme seeks to prevent depositors' investment, it may promote banks to take more risky activities thereby increasing the chances of their failure as well as the failure of the financial system. Hanc (1999) also states that the deposit insurance schemes create incentives for insured banks to take increased risks. Choi (1999) added that providing protection to a risk-taking financial institution may encourage it to take greater risk with depositors' money because it can pass negative consequences on to the deposit protection agency. Government of Nepal (GON) as well as Nepal Rastra Bank (NRB), therefore, needs to come up with appropriate measures to counterbalance the risk of systemic failure due to their intervention, initiating deposit insurance scheme without proper study. Till date neither the GON nor the NRB seem to have devised some solid measures to tackle this problem. If government supervision and regulation of banks is lax, bank failures can be more likely than in the absence of deposit insurance (Pennacchi, 2009). Moreover, there is even the question of efficiency, supervisory capacity, as well as availability of required number of skilled human resources with GON and/or NRB. This is a bit concern for all the stakeholders. But as quoted by Demirguc-Kunt et al. (2008) external pressures from institutions such as the International Monetary Fund, the World Bank, etc as well as due to the financial crisis of 2008, global development in this regard, failure of NDB, and the domestic political pressure might have influenced the decision of NRB (or the GON), in this regard.

Public attitudes and expectations play a particularly important role in reinforcing the credibility and the effectiveness of a deposit insurance system (FSF, 2001). For the deposit protection agency to operate effectively and efficiently, it must win the confidence of the public (Choi, 1999). To ensure the success of deposit insurance scheme as well as to increase the confidence of customer on the banking system, insurers ought to create awareness about this system and convince the public of the security of their deposit, may be by means of advertisement in the mass media. This is because without the public understanding the system, deposit insurance scheme could not be effective and the public could not be made aware of the 
reduced incentive for withdrawing their insured deposits. However, it seems that neither DCGC nor NRB or GON feel it the priority as well as lack any incentive to properly publicize these facts. Thus, most of the customers were even not aware of these types of development in the financial market even in the urban areas, leave apart the rural areas. The public seem to be the neglected part of Nepalese deposit insurance scheme and public awareness not the responsibility of insurers or any of the government authorities. Besides, although membership expiries will be published through national level daily newspaper, there is no provision for membership grants. The banks may feel biased, in this regard, too.

Regarding membership, in the initial stage the membership may be made compulsory but after a certain period, the membership could be changed to voluntary, for example after 5 years. This is justified in the sense that the principle of volunteering increases the chances of cooperation, timely compliance, and increase efficiency in other matters. Besides, by that time it could be assumed that public will be aware of this system and there are fewer incentives for the banks to withdraw from the deposit insurance scheme and take risk of losing customers. This could be more effective if DCGC/GON/NRB publicize the list of banks adopting the deposit insurance scheme so that no banks will risk facing the consequences due to public pressure. Hence, this could be the indirect incentive for the participating banks, however, voluntary participation will create a win-win situation for all the parties. Even if some banks choose to opt out, it will reduce the burden on government budget, if severe financial crisis occurs and also the burden on taxpayers. In addition, since deposit insurance creates incentives for insured banks to take increased risks, it generates substantial costs for monitoring and restraining bank risk (Hanc, 1999), and few membership means reduced cost burden to regulators and/or government. Although, the author does not feels that any institutions should be left from deposit insurance scheme, it is advocated that voluntary nature of scheme may make the banks feel that they are not enforced to carry additional burden out of their wish.

The other issue is that of coinsurance. Coinsurance (which limits the proportion of protected deposits) impel depositors to exercise some care in choosing a depository institution (Choi, 1999). Therefore, it would be better to state the range of amount to be insured, for example, from NPR 50,000 to 500,000 . This will, on the one hand, reduce the financial burden on the participating banks and, on the other hand, increase the incentive for depositors for creating the habit of savings. It is also justified because since at present Gross National Saving of Nepal is very low, compared even to the developing countries of South Asia. Further, this could be supplemented by prioritizing deposits up to NPR 50,000 (first claim) while liquidating an institution. Thus, the problem and concern of all the stakeholders including banks, depositors, and GON will be solved by adopting this approach.

Since, whoever will be the shareholders of the deposit insurer they could not be forced to pay the liabilities of the insurer above their equity and that the deposit guarantee fund may not be enough to cover its liabilities, if some banks go bankrupt in the initial stage of establishment of this fund or if several banks go bankrupt even after the deposit guarantee fund have collected significant amount 
of money (funds). The deposit insurer must also have sufficient fund base and financial soundness to increase customers' confidence that their deposits are safe and certain to be refunded. This is because the deposits of the banks that need to be insured amount to around NPR 200 billion (or more) and even if it is assumed that the probability of failure is $1 \%$, the deposit to be reimbursed comes out to be around NPR 2 billion, which will be a considerable sum that could not be paid even by the whole capital of the Nepalese deposit insurer. Even at present, the capital base of DCGC is at around NPR 1 billion and since it has not explicit government backing, it could not be believed that it will insure hundreds of billions of deposits held at banks. However, Choi (1999) have a different view on this aspect and he argues that the deposit protection agency does not require capital. Also, if it had a financial backer, its autonomy could be undermined. Initial funding may be needed to operate the agency, but this could be achieved through contributions and endowments which the deposit protection agency should repay after a certain period. Although, it may be true in some aspect, but without the government backing, public may not have a relief of mind and full confidence on the system. When funding is inadequate, the difficult issue arises as to how funds should be collected after bank failures (Schich, 2008). Add to it the lack of explicit backing by the government. This makes the credibility of Nepalese deposit insurer at the lowest. In this sense, even the insurer could go bankrupt unless GON backs it. The government alone has the resources to run such a system and absorb the costs of bank failures (Choi, 1999). Also since for the deposit protection agency to operate effectively and efficiently, it must win the confidence of the public and hence for this reason, the agency should be a public institution. Hence, the government needs to fully back this organization. GON (or NRB) could play the role of a guardian and publicize its financial backing for the DCGC, in case it was unable to pay its liabilities. In absence of this explicit guarantee, neither the banks nor the depositors will be fully confident about the efficacy of this schemes as well as safety of the deposits. Looking at the world trend, most of the countries having deposit insurance scheme now have explicit government guarantee. So, Nepal should not hesitate from the best international as well as from the best practical approach, and build up public confidence on the banking system. Furthermore, as deposit protection must be transparent, most countries have established explicit deposit protection schemes (Choi, 1999). Explicit, limited-coverage deposit insurance is preferable to implicit protection if it clarifies the authorities' obligations to depositors and limits the scope for discretionary decisions that may result in arbitrary actions (FSF, 2001). The deposit protection system should be explicit rather than implicit also because the implicit deposit protection system does not distinguish clearly between the protection of financial institutions and the protection of depositors. The government could therefore end up protecting insolvent financial institutions when it should be protecting only the depositors. Implicit schemes protect depositors by preventing the collapse of financial institutions, whereas the managerial responsibility is rarely asked of these financial institutions, resulting in a less competitive and less efficient financial industry. The cost of implicit systems falls heavily on taxpayers, whereas explicit systems normally require financial institutions to cover the costs except in an economic emergency. Therefore, a recent tendency is for countries to adopt explicit systems because of these inherent problems with implicit schemes (Choi, 1999). 
High premium payable is another major issue. It is making banks reluctant to join (although ultimately they may need to join), reluctant to pay the premiums, reluctant to cooperate and provide actual data, increase moral hazard since banks are faced to increase profits by taking more risks to cover these premiums, decreased deposit interest rate, or putting the burden of these premiums ultimately to the depositors. Since, deposit insurance premium seem to be very high (as would be evident from the subsequent section) and one of the major issues, this will be dealt in detail under another heading.

It also seems that deposit insurer is benefitted from all sides. This is because usually saving-account and fixed-account holders can get their money back from the liquidation of the banks (they are prioritized in the liquidation process). Asset recovery will make other depositors too less vulnerable in the long run. The only sufferer then will be the shareholders since neither insurer nor the liquidation seems to cover their investment amount. Therefore, the provision of solely covering the liability of small depositors should be made to deposit insurer and the money obtained from liquidation process be provided to others than those benefitted by the deposit insurance coverage, according to the priority set in the law. Deposit insurer should not be reimbursed from the liquidation or the priority of insurer should be at the last, after all other stakeholders have been paid up fully.

There are certain conditions proposed when claims may be disqualified. One such term for disqualification is stated as failure of banks to comply with laid down procedures/reporting and/or timely payment of the dues. In such case, if any banks were not to comply for whatsoever reason, which is not a fault of the depositors, how will the depositors be protected? If the government is really concerned with the protection of small depositors than this provision seems absurd. They must find other ways to punish the banks but avoid making the public the scapegoat for its negligence or wrongdoings.

Refund or reimbursement of insured deposit by the Nepalese deposit insurer takes around 90 days. If it would be the case, the refund period would look very long. Since, the liquidator already provides the eligible depositors' list, the period should be 30 days or so to relieve the depositors and make them feel the existence of effective deposit insurance program.

Several tasks has been remaining but the deposit insurer has already started insuring deposits. It will not only bring about legal hassles but also raise question on several issues like the procedural/practical issues. Besides, deposit insurance scheme has been operated by NRB, which is also not desirable. Insurer should be made an independent body neither under the direct leadership of either the government or NRB, although it seems to be the case at present. The deposit insurance agency should be independent of the government, the central bank, and supervisory agencies, and maintain a relationship of mutual checks and balances with those agencies (Choi, 1999). Since, to be more effective and reduce costs, it needs close cooperation and coordination with the supervisory function. 
Nepal has also mixed up two entirely different institutions. Since, credit guarantee and deposit guarantee are two different matters requiring different types of work, skills, technology, and human resources, it would be better to separate these entities. This could be done by establishing a new "deposit-only" insurer, making new rules and regulations, and considering other related matters. This will also reduce the burden on the single institution both in terms of workload and financial load as well as reduce the risk due to simultaneous failures of banks and/or borrowers. Most of the deposit insurers are established as a separate entity throughout the world and the percentage of countries combining these two are rare $^{8}$ (Demirguc Kunt et al., 2005), which also justifies the need of separate entities.

Provision of lending funds to banks, directly or indirectly through NRB, is also desirable since it would be beneficial to DCGC itself, because banks will be avoided from being insolvent with this liquidity injection. Similarly, after a certain level of fund accumulation premium collection may be halted, which will send positive message that DCGC does not have profit-only motive rather wish to establish a safety-net for banks' own interests. Furthermore, it should be also on cards of DCGC to return back money to banks after a certain specified time, say 5 years, similar to that in case of insurance business.

Besides the deposit protection agency, an asset management corporation may be established to call in claims through the sell-off of non-performing assets that arise during the resolution of insolvencies, as has been done in Korea and Thailand (Choi, 1999). Although, establishment of Asset Management Company has been in the wish-list of both public and private sector and has been discussed extensively in the past (NRB, 2002), it has not materialized yet and this may be the right time and a great opportunity, in this regard.

\subsection{Comparison of Nepalese deposit insurance system with others}

The comparison of deposit insurance systems/schemes in different countries is important to find out the practices prevalent throughout the world and to help guide the development of best practices in the domestic context. It is expected that these comparisons will prove to be a good guide to the policy makers as well.

First, the deposit insurance system of some of the South Asian countries have been discussed, since they exert the most influence and set a standard for Nepalese context (Table 1). The table presents essential features of Indian, Malaysian, Sri Lankan, and Bangladeshi deposit insurance system. It seems that Afghanistan, Bhutan, and Pakistan are yet to formally establish and/or operationalize the deposit insurance system in their respective countries. However, there is some informal information about the deposit insurance scheme in case of Pakistan. A draft Deposit Protection Fund Act has been prepared on 2008 but the whereabouts of the progress is yet difficult to find. Some years back there had been a report suggesting probable features of the Pakistan's Policy on deposit insurance. The report suggested that a Deposit Protection Fund is proposed to be established under the State Bank of Pakistan, all commercial banks will be mandatorily required to be its member, up to Pakistani Rupees 100,000 will be protected under this scheme 
(which covers around $94 \%$ of all the accounts), and that the premium will be on the flat rate basis at $0.02 \%$ (IMF, 2004). Afghanistan has also come up with an organization and some provisions related to deposit insurance but it will not be dealt herein.

Most of the South Asian countries were found to have mandatory provision for membership and all the banks and financial institutions should be participating in the scheme. Regarding the organizational setup, India have Deposit Insurance and Credit Guarantee Corporation entitled to carry out the deposit protection scheme. Nepalese system also seems to be influenced by this and there is a Deposit and Credit Guarantee Corporation for this purpose. Most of the other countries, not only South Asian but throughout the world seem to separate deposit and credit guaranteeing function. Besides, Nepalese organization seems to be the only one that is a private organization and have only an implicit guarantee from the government instead of an explicit backing. Other countries, however, have these types of organization under the direct purview of Central Bank and/or is established as a government body and/or have an explicit backup from the government.

The amount of money (throughout this paper local currency of the respective country has been used unless specified otherwise) insured is also high in Nepal and except Malaysia it is around twice or more than other South Asian countries. On the other hand, the premium charged on the banks is also highest in the case of Nepal. Although, the highest premium level for Malaysia is slightly higher than that of Nepal but since it has differential rates, the flat rate in Nepal seems to be seven times higher compared to the lowest rate of Malaysia. Malaysia have categorized banks into 4 categories based on risk etc and the premium rate also doubles for each category (e.g. $0.03 \%, 0.06 \%, 0.12 \%$, and $0.24 \%$ ), however, there is also a minimum limit of payment each category of bank should pay. Looking at the Indian rates, it is half that of Nepal. A few years back it was even $0.05 \%$ (one-fourth of Nepalese premium rates), and was revised upward due to excessive failure of Cooperatives. In case of Nepal, since cooperatives are not insured the chances of failures thus seems to be very low compared to India and hence reimbursement by the organization will also be less, which warrantees the need of lower premium based on the principles of probability theory (based on the principles of probability of loss). Sri Lanka also have an affirmative pricing policy based on, for example, Capital Adequacy Ratio, and based on the type of banks as well as payment frequency (monthly, quarterly, etc).

Malaysian scheme covers around $90 \%$ of all the account holders but there is no data on part of Nepalese scheme and it is not known what is the basis of setting these levels of insured deposits. The only basis seems to be politically driven agenda of the government. Recently due to the government agenda, the insured deposit was increased from existing NPR 200,000 to 500,000. It would have been better if NRB or DCGC come up with appropriate objective of protecting certain level of deposits, which should not be based on any vested political interest. The current level of insured deposit of NPR 500,000 could be higher or even lower than the desired level of protection required by the public. Setting the level of insured deposit by giving consideration on average deposit level, inclusion of maximum 
number of accounts of natural persons, per capita income or per capita GDP, etc would have been reasonable and scientific basis, in this regard. Usually it is being recommended that $80 \%$ of the total depositors or $20 \%$ of the total deposits should be insured.

Table 1: Comparison with South Asian Countries

\begin{tabular}{|c|c|c|c|c|}
\hline Country & Organization & Type of Organization & Amount & Premium (\%) \\
\hline Nepal & $\begin{array}{l}\text { Deposit and Credit } \\
\text { Guarantee } \\
\text { Corporation Pvt. Ltd. }\end{array}$ & $\begin{array}{l}\text { Private (but } \\
\text { managed by NRB) }\end{array}$ & NPR 500,000 & $0.2 \%$ \\
\hline India & $\begin{array}{l}\text { Deposit Insurance } \\
\text { and Credit guarantee } \\
\text { Corporation }\end{array}$ & $\begin{array}{l}\text { Reserve Bank of } \\
\text { India Subsidiary }\end{array}$ & INR 100,000* & $0.1 * *$ \\
\hline Malaysia & $\begin{array}{l}\text { Malaysia Deposit } \\
\text { Insurance Insurance } \\
\text { Corporation }\end{array}$ & Government Body & RM 250,000* & $0.03-0.24 \% *$ \\
\hline Sri Lanka & $\begin{array}{l}\text { Deposit Insurance } \\
\text { Fund (Monetary } \\
\text { Board) }\end{array}$ & $\begin{array}{ll}\text { Managed } & \text { under } \\
\text { Central Bank of Sri } \\
\text { Lanka }\end{array}$ & S. Rs. 200,000 & $0.1-0.15 \%$ \\
\hline Bangladesh & $\begin{array}{l}\text { Deposit Insurance } \\
\text { Trust Fund }\end{array}$ & $\begin{array}{l}\text { Managed under } \\
\text { Bangladesh Bank }\end{array}$ & Taka 100,000 & $0.07 \%$ \\
\hline
\end{tabular}

Taking the similar variables, as above, the comparison have also been made with some other Asian countries (Table 2). Needless to say, since $90 \%$ or more countries have made it compulsory, these countries are also not exception. Although government owned banks, foreign bank branch, and Islamic banks and a few others may not be provided membership. However, all these countries seems to have deposit insuring organization either directly owned by government or even if a semi-government or non-government organization, they are fully backed by the government with explicit government guarantee on deposit reimbursement. Japan has established a semi-government institution owned also by the banks. Singapore, on the other hand, have the non-government institution but it is formed by government act as well as there is a provision that this institution should report to the Central Bank as well as Finance Minister, periodically.

Thailand started deposit insurance scheme by providing full blanket guarantee till August 2011, which has been reduced to 50 Million Baht for up to August 2012, and after August 2012 it will be further reduced to 1 Million Baht. But even the 1 Million Baht limit seems to cover around $98.5 \%$ of the deposits. Similarly, other countries also have differential guarantee amount. Regarding the premium rates, Nepalese system is still higher than most of these relatively well-off countries, except Thailand. Hence, it is very unusual for the Nepalese policy makers to decide on premiums without proper research even in the neighboring Asian countries. 
Table 2: Comparison with selected Asian Countries

\begin{tabular}{llrr}
\hline Country & Organization & Amount & Premium (\%) \\
\hline Thailand & $\begin{array}{l}\text { Deposit Protection Agency } \\
\text { Deposin } \\
\text { of Japan }\end{array}$ & 50 Million Baht & 0.4 \\
Singapore & $\begin{array}{l}\text { Singapore Deposit Insurance } \\
\text { Corporation }\end{array}$ & 10 Million Yen & $* 0.081-0.107$ \\
Korea & - & S $\$ 50,000$ & $0.02-0.07$ \\
Philippines & - & US\$ 14600 & $* * 0.05$ \\
\hline (Source: DICJ, 2009; DPA, 2011; JDIC, 2011; NRB, 2011U; MAS, 2011; SDIC, 2011a; SDIC, 2011b) & P 100,000 \\
Note: * 0.08\%1 for general deposits; ** of total deposits; *** of deposits &
\end{tabular}

Compared even to other developing or under-developed countries of the world, it seems that premium policy of Nepal is biased (Table 3 and Annex I, Table A1). Although there is a lack of several data, the insured amount as well as premium levels set by Nepal seems to be very high, compared with these countries. Due to lack of resources, this research could not compare other issues than organizational setup, government backing structure, premium levels, etc which is the limitation of this study. It would have been better if legislation of different countries could be compared, in this regard.

Table 3: Comparison with selected Developing / Under-Developed Countries

\begin{tabular}{lrr}
\hline Country & Amount & Premium (\%) \\
\hline Kenya & K Sh 100,000 & $0.15 \% *$ \\
Tanzania & T Sh 250,000 & $0.1 \% *$ \\
Lebanon & LL 30,000 & $0.02-0.05 \%$ \\
Jamaica & J 600,000 & $0.15 \%$ \\
\hline (Source: JDIC, 2011) & &
\end{tabular}

\subsection{Deposit insurance premium}

It seems that banks are convinced that deposit insurance scheme is necessary and need to be implemented. Even, based on the sound financial management, policy makers could not step back from establishing deposit insurance scheme. However, the major controversial issue is of that of premium rates. Insurance premiums refer to premium payments made by financial institutions according to the probability of that institution becoming unable to meet withdrawals (Choi, 1999).

Insurance premiums are based on a flat or a differential rate. Flat rates, for which a fixed percentage of deposits is designated, are easier to estimate and less expensive to administer, and are therefore prevalent among countries with explicit deposit insurance systems. But a differential rate is more effective in preventing moral hazard and instituting prudential management. As differential rates are more complicated, however, it is best to start with a flat rate and to shift to a differential rate after the deposit protection framework has been place for some time (Choi, 1999). Since, Nepal adopted a flat-rate system, banks, especially higher category and well managed banks, are of the view that they are unfairly priced whereas 
those institutions that are highly risky are subsidized on their cost, that is, by adding unnecessary cost to them.

Ideally, any pricing system would possess some combination of five attributes: accuracy, simplicity, flexibility, appropriate incentives, and fairness (Bloecher et al., 2001). Looking at present provision, banks had to pay a flat rate of $0.20 \%$ of insured deposits. This amount is divided into two equal halves payable at 6 months interval, within 30 days of end of respective quarters (based on Nepali calendar). Additional penalty of $0.10 \%$ is levied for those banks with less than minimum required CAR (Capital Adequacy Ratio). There is also a fine of $25 \%$ and $50 \%$ of the amount payable if the banks were unable to pay the premium within 30 and 60 days of the deadline for payment. Thus, the financial burden on banks seems to be very high due to the introduction of deposit insurance scheme.

It seems that the premium rates were suggested based on the Indian rates for the same, adding to it some space for absorbing additional shocks. These rates are neither based on any scientific approach or probability hypothesis based on expected loss. Rather the regulators find it easy to pick up rates of neighboring countries and add to it some margin (reaction of over consciousness) so that there is a minimum chance of loss to the newly established organization, the deposit insurer. Also, it is overlooked that Indian deposit insurer initially fixed the rate at $0.05 \%$ and with the increasing failures of Cooperatives it was increased to $0.10 \%$. But in the Nepalese context, there is no need to be highly conscious. This is because there are relatively little number of banks registered and regulated by the NRB and that Cooperatives does not fall under the scheme of deposit insurer. Hence, the premium rate could be reduced to $0.05 \%$ at the initial stage and reviewed later, if the insurer feels the need for it. High premium payable also make banks reluctant to pay, reluctant to cooperate and provide actual data, increase moral hazard since banks are faced to pressure to increase profits by taking more risks to cover these premiums, decreased deposit interest rate or putting the burden of these premiums ultimately to the depositors, may be indirectly.

Also, the premium should be fixed on the basis of financials of concerned institutions rather than fixing it on the flat basis. In this regard, the premium fee could be differentiated between banks depending on risk, for example, through risk weightage on each banks determined by say a Rating Agency (even NRB does some sort of rating based on CAMELS etc, which could be used in the initial phase). However, since Nepal has yet not introduced any Rating Agencies formally (although it has been discussed extensively in the past; NRB 2003), at the initial stage of introducing the differential premium rates, one option would be to have only two or three premium categories and keep the spread small between those categories so that a drastic change in financial institutions' burden of premium payments would be avoided, ensuring their support for a new premium rates structure (DIC], 2004).

The following could be implemented to reduce the concern of participating member banks regarding the premium rates. Until, the ratings of banks are done by some rating agency, the affirmative price could be adopted based on the category of the 
bank as per NRB: Class A: $0.05 \%$; Class B: $0.10 \%$; Class C: $0.20 \%$; Class D: $0.10 \%$. Later on, it could be adjusted for more features and discriminated more on the basis of individual banks' risk. This is also justifiable under the background that none of the Class-A bank have been failed till date. However, one Class-B bank had already failed and several Class- $C$ banks are in the verge of failure. It also increases market discipline since banks strive to become more secure (less risky) in order to pay less premium. Whereas, Class-D institutions has been encouraged by lesser premium due to their outreach to poorer segment of the community and role to increase access to financial services and cover the segments not covered by other class of banks (government also promotes these microfinance institutions, in this regard). Besides, they are less risky and almost have $100 \%$ loan recovery rates ${ }^{9}$. Furthermore, since almost all of their deposit fall under the coverage of proposed deposit insurance scheme, the cost burden to these institutions will be high and passing on to their customers, who are usually poor and marginal households, will not be desirable.

Looking at the recent increase in the levels of insured deposit by the GON, from NPR 200,000 to 500,000 , which will sooner or later implemented by NRB and/or CDGC, it is more than reasonable that the concerned authorities come up with revised premium rates, also because with the new provision their revenue may shoot up more than twice. Due to increasing dissatisfaction of private sector and as per agreed upon during the recently held talks between stakeholders, NRB has made a Task Force to study the possibility of reducing the premium, to the extent possible (NBF, 2011), which seems to be a positive step, in this regard.

Also, the need and availability of re-insurance (co-insurance) should be looked into. It is better to adopt a coinsurance system (which limits the proportion of protected deposits), which impel the depositors to exercise some care in choosing a depository institution (Choi, 1999). In this regard, it would be better to insure the deposits within some range, for example, from NPR 50,000 to 500,000. This will, on the one hand, reduce the financial burden on the participating banks and, on the other hand, increase the incentive for depositors for creating the habit of savings.

\section{CONCLUSION AND RECOMMENDATION}

Since, banks are prone to failures establishment of proper safety-nets is a must. Deposit insurance is one of the options to safeguard the interest of depositors as well as to maintain financial stability. However, it seems that while introducing a deposit insurance scheme in Nepal, a thorough study have not been conducted and the government authorities introduced it all of a sudden. There are a lot of contentious issues that even the government agencies seem not to be clear of. This research tried to fulfill this gap, to some extent. In this research, the focus is to explore the basic principles of effective deposit insurance system and the practices and trend in the different countries throughout the world, with emphasis on the South Asian countries. It has been also tried to compare these findings with the Nepalese system. The research also explores and highlights the major contentious issues in the Nepalese case. 
It was found that there are several issues in the Nepalese deposit insurance scheme that need to be addressed based on best international practices and based on basic principles of deposit insurance system. As per the core principles of an effective deposit insurance scheme, policy makers should prepare a way out for the Nepalese deposit insurance system.

Although, deposit insurance scheme was introduced citing the failure of one of the banks, namely the Nepal Development Bank Ltd., the so-called small depositors (as per the NRB definition) seem to have been reimbursed in full. Despite this the depositors need assurance for future of their deposits and hence the need of the deposit insurance system could not be undermined. But looking at the current provisions, Nepalese deposit insurance seems not to achieve its expected objectives. First point is that deposit insurance system brings about moral hazard not only on part of banks but also depositors, since they feel risk-free even to take the riskiest institution offering highest premium in the form of interest. Also, since banks can pass on the negative consequence to the deposit insurer, they are prone to increased risk and increased failures. However, the supervisory capacity of the regulators seems to be compromising even at present, and expectation of it being improved drastically in the near future is pointless. Although enhanced capacity or regulators is a must to counteract the possible negative effects due to the introduction of this new provision and it would be better to improve the supervisory capacity of the central bank by capacity building as well as by the increase in the number of skilled human resources, for effective monitoring and supervision.

The concerned parties (government authorities including the deposit insurer, that is, DCGC) also seem to have publicized very little about this scheme to create awareness in the public about reduced incentives for withdrawing money due to possible fear of bank's failure. Without proper knowledge on part of public, this system may not work as effectively as envisaged. Hence, this should be prioritized and publicized in the mass media as well as through other means like distribution of brochures, leaflets, etc. Of course, to have a full confidence of public, first of all, the deposit insurer of Nepal must have explicit backing from the GON or NRB. This should also be highlighted while campaigning for public awareness. Without, explicit government guarantee the system may not have sufficient support from public. Schich (2008) even suspect that there may be possibility that even the capacity of some governments to provide for the guarantee that they have announced or implied in announcements may be questioned. In such a scenario, one could expect that the public opinion will not be favorable, if government hesitates from directly showing their support for the system.

There are some other issues also. Membership could be made voluntary with some incentives for the participating banks, may be after certain period, to enhance the cooperation of banks as well as to enhance the feeling of ownership. Protection of shareholders equity should also need consideration. This will send a positive message and effect positively on the capital generation, which is at the lowest at present. This may be done by prioritizing shareholders before deposit insurer in case of liquidation. Depositors should also not be made scapegoat at any cost and there should be full assurance that their insured deposit, by virtue of membership 
taken by their institution, will be refunded at any cost despite technical problems like banks failing to comply with the provisions made by deposit insurer. Deposit refund period also need to be revised since 90 days is too long and depositor may lose patience while waiting for such a long period. Besides, small depositors may also suffer several problems if they are not availed with their deposits immediately. Provision of deposit withdrawal anytime, even if the bank is declared problematic or being considered for liquidation, is required to feel the existence of effective deposit insurance scheme.

Looking at the global trend, it would also be better to separate the function of guaranteeing deposits and credits and establish a new entity for deposit guaranteeing. Possibility of establishing a Rating Agency and also an Asset Management Company should also be explored. These are long pending and this might be the right time for the same. Also, release of fund held at deposit insurer to other safety-net participants, like NRB, and a close working relationship with these institutions is also desirable and hence provision need to be made, in this regard.

Since, one of the major issue of controversy seems to be the premium rate, which seems to be very high compared to other neighboring countries as well as compared to developing and under-developed countries, it need to be revisited. In this context, this research proposes that the policy makers and/or regulators should try to make differential premium rates as follows based on different classes of banks: Class-A: $0.05 \%$; Class-B: $0.10 \%$; Class-C: $0.20 \%$; Class-D: $0.10 \%$. Or if it is not possible at present, a flat rate of $0.10 \%$ will be appropriate for the time being. Introduction of coinsurance, that is, insuring a certain range of deposits, along with the provision of prioritizing the uninsured level of deposits while liquidation may also be another way out to reduce the burden of premium payments, which is highly likely to be passed on to the depositors rather indirectly, making them loose millions of rupees yearly.

Introduction of any new rules and regulations faces opposition from related stakeholders, and this is a regular phenomenon. Introduction of deposit guarantee scheme increases workload as well as costs on part of the participating banks and it is natural that they would oppose it. Besides, it demands skilled human resources as well as training and exposure for existing human resources. It may even give regulatory and supervisory power to the deposit insurer, meaning more burden to the banks. A compromise need to be made to find a mutually agreeable point of transit to future. Banks need to understand that deposit insurance is a part of safety-net and is beneficial for the financial sector, since it helps maintain confidence in the financial system and maintains stability. Besides, since financial institutions charge their insurance premiums to the deposit protection system, there is less need for them to maintain liquidity reserve ratios at the levels normally prescribed by the central bank to cover unexpected withdrawals. Lower liquidity reserve ratios can therefore be set. The swift disposition of unsound financial institutions, through such a system, will pave the way for renewed competitiveness in the financial industry (Choi, 1999), and is desirable for efficient market players. Hence, it is recommended that banks be positive towards it and cooperate with the 
regulators and government authorities to fully accomplish the objectives of this scheme.

\section{NOTES}

${ }^{1}$ If poorly designed, it may increase risks, notably moral hazard. Moral hazard refers to the incentive for excessive risk taking by banks or those receiving the benefit of protection. Such behavior may arise, for example, in situations where depositors and other creditors are protected, or believe they are protected, from losses or when they believe that a bank will not be allowed to fail. In these cases, depositors have less incentive to access the necessary information to monitor banks. As a result, in the absence of regulatory or other restraints, weak banks can attract deposits for high-risk ventures at a lower cost than would otherwise be the case.

${ }^{2}$ In order for a deposit insurance system to be effective, it is essential that the public be informed about its benefits and limitations. A public-awareness program can build or help restore confidence in the banking sector. Therefore, policymakers should ensure that the authorities and the public view all components of the deposit insurance system as credible. The level and scope of coverage, the speed with which insured deposits are repaid, and the credibility of the underlying guarantee will affect its efficiency.

3 Pay-box systems largely are confined to paying the claims of depositors after a bank has been closed. Accordingly, they normally do not have prudential regulatory or supervisory responsibilities or intervention powers.

4 A "risk-minimizer" deposit insurer has a relatively broad mandate and accordingly more powers. These powers may include: the ability to control entry and exit from the deposit insurance system, the ability to assess and manage its own risks, and the ability to conduct examinations of banks or request such examinations. Such systems also may provide financial assistance to resolve failing banks in a manner that minimizes losses to the deposit insurer.

${ }^{5} \mathrm{FY}=$ Fiscal Year; Nepal have its own calendar, different than the Western one (English Calendar). Fiscal year starts from fourth month, Shrawan (corresponds to July/August), and ends on third month Ashad (corresponds to June/July). Besides, the year is nearly 57 years earlier than the English calendar, for example, Year 2011/12 corresponds to year 2068/69.

${ }^{6}$ NPR = Nepalese Rupees; US\$ 1 = NPR 80, approximately as of October 2011 (NRB, 2011)

7 DCGC = Deposit and Credit Guarantee Corporation Pvt. Ltd.; It is the deposit insurer of Nepal. It is formed by the DCGC Bylaws, 2067.

${ }^{8}$ As per the report of Demirguc Kunt et al. (2005), it seems that India only is the country combining two separate functions, deposit guarantee and credit guarantee, under the same organization. Nepal later adopted the similar practice. There is, however, some confusion over the practice of Germany and Mexico, among a few other countries. It is not clear whether or not they had separate organization for these two functions.

${ }^{9}$ Since, they provide small loans to a large number of clients, based on group guarantee, market failures have little impact on these institutions. Data also showed near $100 \%$ loan recovery rates of these types of institutions (Selvi and Karuppasamy, 2010) again conforming that failures are rare.

\section{REFERENCES}

BB. 2009. Prudential Regulations for Banks: Selected Issues (updated till June 2009). Bangladesh Bank, Dhaka, Bangladesh.

BIS. 2009. Core Principles for Effective deposit insurance Systems. Basel Committee on Banking Supervision and International Association of deposit Insures, Bank for International Settlements.

Bloecher, E. P., G. A. Seale, and R. D. Vilim. 2003. Options for Pricing Federal deposit insurance. FDIC Banking Review, Vol. 15 (4), Pp. 1-17.

CBS. 2010. Sri Lanka Deposit Insurance Schemes Regulation. The Gazette of the Democratic Socialist Republic of Sri Lanka - Extraordinary (2010.09.28), Part I, Section I, Monetary Board, Central Bank of Sri Lanka. 
Choi, J. B.. 1999. Structuring a deposit insurance System from the Asian Perspective. Rising to the Challenge in Asia: A Study of Financial Markets, Vol. 02 (Special Issues), Pp. 66-102.

DCGC. 2010. Deposit guarantee Bylaws, 2067. Deposit and Credit guarantee Corporation, Nepal.

Demirguc-Kunt, A., B. Karacaovalu, and L. Laeven. 2005. Deposit insurance around the world: a comprehensive database. Policy Research Working Paper Series\#3628, The World Bank.

Demirguc-Kunt, A., E. J. Kane, and L. Laeven. 2008. Determinants of depositinsurance Adoption and Design. Journal of Financial Intermediation Vol. 17 (3), Pp. 407-438.

DICGC. 2006. A Guide to the Deposit Insurance System. Outline of the System and Questions and Answers, Deposit Insurance and Credit Guarantee Corporation, India.

DICJ. 2004. Interim Report by the Study Group on the deposit insurance Premium. Deposit insurance Corporation of Japan.

DICJ. 2009. Deposit insurance System in Japan (including international comparison with the USA and he UK). Deposit insurance Corporation of Japan.

DPA. 2011. Frequently Asked Questions. Deposit Protection Agency, Thailand. http://www.dpa.or.th/Detail.aspx?menu=22\&id=50. Accessed on 2011.9.16.

FDIC. 2011. When a Bank Fails - Facts for Depositors, Creditors, and Borrowers. http://www.fdic.gov/consumers/banking/facts/. Accessed on 2011.10.20.

Federal Register. 2009. FDIC - Assessments (12 CFR Part 327, RIN 3064 - AD 35). Federal Register, Vol. 74 (41), Pp. 9525-9563.

FSA. 2011. Financial Services Compensation Scheme Funding. FSA Handbook, Chapter 6, Financial Service Authority, UK.

FSCS. 2011 (a). FSCS - About Us. Financial Services Compensation Scheme. http://www.fscs.org.uk/what-we-cover/about-us/. Accessed on 2011.10.19.

FSCS. 2011 (b). FSCS - Compensation Limits. Financial Services Compensation Scheme. $\quad$ http://www.fscs.org.uk/what-we-cover/compensation-limits/. Accessed on 2011.10.19.

FSF. 2001. Guidance for Developing Effective deposit insurance Systems. Financial Stability Forum, Financial Stability Board, Basel, Switzerland.

Hanc, G. 1999. Deposit insurance Reform: State of the Debate. FDIC Banking Review, Vo. 12 (3) Pp. 1-26.

IMF. 2004. Pakistan: Financial System Stability Assessment including Report on the Observance of Standards and Codes on the following topics: Monetary and Financial Policy Transparency, Banking Supervision, and Securities Regulation. IMF Staff Country Report \# 04/215, International Monetary Fund, Washington DC, USA.

JDIC. 2011. Deposit insurance scheme - A comparative analysis. Jamaica deposit Insurance Corporation. http://www.jdic.org/depositinsuranceschemes.htm. Accessed on 2011.09.16.

MAS. 2011. Deposit Insurance Regulations 2011. Deposit Insurance and Policy Owners' Protection Schemes Act 2011, Act 15 of 2011, Monetary Authority of Singapore, Singapore. 
MDIC. 2011. MDIC (Annual Premium and First Premium in Respect of DepositTaking Members) Order 2011. MDIC Act 2011, Malaysian Deposit Insurance Corporation, Malaysia.

NBF. 2011. Issues and Decisions Summary. Decisions made by the joint meeting of Public and Private Sector Co-Chairs of Finance, Monetary, and Insurance Working Group, Nepal Business Forum, held on May 30, 2011. http://nepalbankers.com/attachments/182_Decision\%20II\%20b.JPG. Accessed on 2011.10.19.

NRB. 2002. Monetary Policy FY 2059/60. Nepal Rastra Bank, Kathmandu, Nepal. NRB. 2003. Monetary Policy FY 2060/61. Nepal Rastra Bank, Kathmandu, Nepal. NRB. 2009. Monetary Policy FY 2066/67. Nepal Rastra Bank, Kathmandu, Nepal.

NRB. 2011. Foreign Exchange Rates. Nepal Rastra Bank. http://www.nrb.org.np/fxmexchangerate1.php?YY=\&\&MM=\&\&DD=. Accessed on 2011.10.23.

NRB. 2011U. Deposit Guarantee - Concept Paper. Unpublished. Nepal Rastra Bank, Kathmandu, Nepal.

Pennacchi, G. 2009. Deposit Insurance. Presented in the conference titled "Private Markets and Public Insurance Programs" held on January 25, 2009 at American Enterprise Institute for Public Policy Research, Washington DC, USA.

PIDM. 2011 (a). What is Deposit Insurance. Perbadanan Insurans Deposit Malaysia. http://www.pidm.gov.my/About-Deposit-Insurance/What-Is-DepositInsurance-.aspx. Accessed on 2011.10.19.

PIDM. 2011 (b). Coverage. Perbadanan Insurans Deposit Malaysia. http://www.pidm.gov.my/About-Deposit-Insurance/Coverage.aspx. Accessed on 2011.10.19.

Schich, S. 2008. Financial Crisis: deposit insurance and Related Financial Safety Net Aspects. Financial Market Trends, Vol. 2008/2 (95).

SDIC. 2011 (a). Frequently Asked Questions. Singapore Deposit Insurance Corporation. http://www.sdic.org.sg/di_faq.php. Accessed on 2011.10.19.

SDIC. 2011 (b). Organization. Singapore Deposit Insurance Corporation. http://www.sdic.org.sg/organization.php. Accessed on 2011.10.19.

Selvi, G. P. and R. Karuppasamy. 2010. Micro Finance in India and Millennium Development Goals: Maximizing Impact on Poverty, International Journal of Research in Commerce and Management, Vol. 1 (7), Pp. 37-42. 


\section{ANNEX I}

Table A1: Comparison with Other Countries*

\begin{tabular}{llr}
\hline Country & Amount & Premium (\%) \\
\hline US & US\$ 250,000 & $7-77.5$ basis points (large banks) \\
Belgium & BF 500,000 & $0.02 \%$ of funded liabilities \\
Finland & $100 \%$ deposits & $0.01-0.05 \%$ \\
Germany & $90 \%$ of deposits or ECU 20,000 & $0.004-0.1 \%$ \\
UK & (? 85,000 (deposits) & $0.2 \%$ (for deposits) \\
Spain & Ptas 1.5 Million & $0.1-0.15 \%$ \\
Norway & No limit & $0.015 \%$ \\
Columbia & $25 \%$ of total or Col $\$ 10$ Million & $0.09 \%$ \\
\hline
\end{tabular}

(Source: JDIC, 2011; Federal Register, 2009; FDIC, 2011; FSA, 2011; FSCS, 2011a; FSCS, 2011b)

Note: ${ }^{* *}$ some countries levy premiums based on insured deposits, a few on total deposits, and a couple of countries even based on total assets. Columbia bases the premium on short term liabilities, savings, and housing, etc; ${ }^{* *}$ US increased the level of insured deposit from US\$ 100,000 to US\$500,000 due to 2008 financial crisis, which seems to prevail till January 2014 when it will be brought down to post-2008 levels. FDIC (Federal Deposit Insurance Corporation) insures deposit in US and is an independent agency of federal government; ${ }^{* * *}$ Financial Services Compensation Scheme, an independent organization, insures deposits as well as investment up to 50,000 and $90 \%$ of insurance amount, among others. 